\title{
Differences in foraging strategy and maternal behaviour between two sympatric fur seal species at the Crozet Islands
}

\author{
Frédéric Bailleul $^{1, *}$, Sebastian Luque ${ }^{1,2}{ }^{2}$ Laurent Dubroca $^{1}$, John P. Y. Arnould ${ }^{3}$, \\ Christophe Guinet ${ }^{1}$
}

${ }^{1}$ Centre d'Etudes Biologiques de Chizé, Centre National de la Recherche Scientifique, 79360 Villiers en Bois, France ${ }^{2}$ Department of Biology, Memorial University of Newfoundland, St. John's, Newfoundland A1B 3X9, Canada ${ }^{3}$ School of Biological and Chemical Sciences, Deakin University, Burwood 3125, Victoria, Australia

\begin{abstract}
Marine top-predators such as marine mammals forage in a heterogeneous environment according to their energetic requirements and to the variation in environmental characteristics. In this study, the behaviour of breeding females in 2 sympatric fur seal species, Antarctic fur seal Arctocephalus gazella and Subantarctic fur seal A. tropicalis, was investigated in relation to foraging effort. Foraging effort was hypothesised to be greater in Antarctic fur seal than in Subantarctic fur seal due to their shorter lactation period. Using satellite telemetry, time-depth recorders and satellite images of sea-surface temperature and chlorophyll a concentration, the foraging grounds, the at-sea activity budgets and the environmental features were determined for both species breeding on the Crozet Archipelago. Foraging cycle duration was similar for the 2 species, and the seals exhibited similar at-sea activity budgets. Only the proportion of time spent at sea was higher in Antarctic fur seals. Separate foraging areas were identified for the 2 species. Antarctic fur seal distribution was related to bathymetric features, while we did not find any direct relationship between chlorophyll $a$ concentration and seal foraging areas. Our results suggest that Antarctic fur seals tend to respond to the higher needs of their pups by having a higher foraging efficiency and concentrating their foraging activity in the most productive areas.
\end{abstract}

KEY WORDS: Activity budget · Spatial distribution · Environmental features · Otariidea · Arctocephalus gazella $\cdot$ Arctocephalus tropicalis

Resale or republication not permitted without written consent of the publisher

\section{INTRODUCTION}

The foraging behaviours of marine mammals are related to the energetic requirements of individuals and environmental characteristics (McCafferty et al. 1998, Costa \& Gales 2003). Indeed, according to optimal foraging theory (McArthur \& Pianka 1966), organisms are supposed to adopt foraging behaviours that optimise fitness for given environmental conditions. These determine how, when and where each animal acquires its food. More precisely, in a 'patchy habitat', according to the marginal-value theorem (Charnov 1976), a predator must make decisions as to which patch types it will visit and when it will leave the patch.
In the marine environment, food resources are distributed heterogeneously in space and time and their distribution is generally related to the heterogeneity in oceanographic features (Pakhomov \& McQuaid 1996, Loeb et al. 1997, Guinet et al. 2001). Distribution and behaviour of top marine predators are related to physical and biological features (bathymetry, sea-surface temperature, primary productivity), as found in seabirds (Bost et al. 1997, Guinet et al. 1997, Weimerskirch 1998) and pinnipeds (Boyd et al. 1998, Georges et al. 2000). Resources are also limited in space and time. If 2 species exploit the same ecological niche and if the resources are limited, ecological segregation resulting from competition between these species should 
inevitably take place (Hutchinson 1957). So sympatric species must have different ecological functions in the ecosystem in order to coexist.

During the breeding season there is a double problem for marine predators: to obtain food for themselves and their offspring. Furthermore, during the breeding period, seabirds and otariids are central-place foragers (Orians \& Pearson 1979), alternating between periods of foraging at sea and feeding their chicks or suckling their pups on land (Bonner 1984, Gentry \& Kooyman 1986). The behaviours adopted by parents are spatially and temporally limited to avoid progeny starvation. Therefore, time and energetic expenditure are the 2 principal constraints for central-place foragers during the breeding season (Ydenberg et al. 1994, Houston 1995).

Among pinnipeds, otariids have the longest lactation period, but with a large degree of variation in its duration. Generally, species that breed at temperate latitudes, like the New Zealand fur seals Arctocephalus forsteri, Juan Fernandez fur seals A. philipii, South African fur seals A. pusillus or Subantarctic fur seals A. tropicalis, suckle their pup for $10 \mathrm{mo}$, while the Alaskan fur seals Callorhinus ursinus and the Antarctic fur seals A. gazella, which breed in high latitudes and productive water, raise their pups over a 4 mo lactation period (Gentry \& Kooyman 1986).

Two species that display markedly different lactation lengths, Antarctic fur seal and Subantarctic fur seal, breed sympatrically on the Crozet Archipelago. At weaning, the size and the body mass of pups of the 2 species are identical (S. Luque unpubl. data), but a previous study showed that in-air resting metabolic rates (RMR) and daily energy expenditure (DEE) were higher in Antarctic fur seal pups than in similar-aged Subantarctic fur seals at Crozet (Arnould et al. 2003). These observations corroborate observations that Antarctic fur seal pups spend more time swimming than in similar-aged Subantarctic fur seal pups (S. Luque, J. P. Y. Arnould \& C. Guinet unpubl. data). We, therefore, hypothesised that Antarctic fur seal females have to expend a higher foraging effort or forage more efficiently to acquire more resources at sea to cover the higher needs of their pups compared to Subantarctic fur seal females. However, amongst marine mammals, the foraging efficiency of parents is not easy to measure, because it is difficult to assess precisely the amount of energy acquired in relation to the energy spent by the female to acquire that energy. One means of evaluating foraging effort is to use the time budget as a proxy of energy expenditure (Arnould \& Boyd 1996, Boyd 1999).

Both species have been studied at their allopatric sites, revealing a variety of foraging behaviours. For example, very long trips (maximum distance from the colony $>100 \mathrm{~km}$ ) were recorded for Subantarctic fur seals from Amsterdam Island (Georges et al. 2000, Beauplet et al. 2004). Similarly, an important variability in the diving activity of Antarctic fur seals was observed at the Kerguelen Islands (Bonadonna et al. 2000, Lea et al. 2002). The sympatric populations of Antarctic fur seals and Subantarctic fur seals at Crozet Island, like at Marion Island (Kerley 1985) and Macquarie Island (Robinson et al. 2002), allow comparisons of the foraging behaviour between 2 taxonomically similar species with different breeding strategies but under identical environmental conditions. The aim of this paper was (1) to investigate the spatial segregation and foraging behaviours of sympatric lactating female Antarctic and Subantarctic fur seals at Crozet and (2) to uncover new aspects of the relationship between foraging behaviours and energy expenditure.

\section{MATERIALS AND METHODS}

Study area and seals. The study was conducted in the Crozet Islands, an archipelago in the Southern Indian Ocean, during the austral summers 2001/2002 and 2002/2003 (December to March). La Mare aux Elephants $\left(46.37^{\circ} \mathrm{S}, 51.69^{\circ} \mathrm{E}\right)$, north-west of Possession Island, accommodates 1 breeding colony. Each species, Antarctic fur seal Arctocephalus gazella and Subantarctic fur seal Arctocephalus tropicalis, has different preferred substrate types, beaches for Antarctic fur seals and rock platforms and large boulders for Subantarctic fur seals, but they breed within a few metres of each other. Population growth rates for both Antarctic and Subantarctic fur seals on this island are currently $\sim 18 \%$ per annum (Guinet et al. 1994, C. Guinet unpubl. data). Annual pup productions at La Mare aux Elephants were 164 for Antarctic fur seals and 80 for Subantarctic fur seals in 2001/2002.

Capture and device attachment. Lactating female fur seals of both species were instrumented. Individuals were selected randomly, captured using a hoop net, weighed and restrained for up to $20 \mathrm{~min}$ on a restraining board while the devices were attached. At-sea behaviour was investigated using several loggers described in Table 1. Time-depth recorders (MK7 TDR, Wildlife Computers) were mounted on a satellite transmitter (platform terminal transmitter [PTT], Sirtack New Zealand, Telonics) in all cases. The larger size of the velocity-time-depth recorders (MK8 TDR, Wildlife Computers) precluded simultaneous deployment of an additional PTT. The package (MK7 + PTT) was shaped to minimise drag and was attached, like the MK8, with plastic cable ties to a nylon webbing strap that was glued on the dorsal midline between the scapulae of each animal with double component araldite glue 
Table 1. Features of logger used ( $\mathrm{x}$ indicates that the parameter is present or measured)

\begin{tabular}{|c|c|c|c|c|c|c|c|c|c|}
\hline \multicolumn{3}{|c|}{ Devices } & \multicolumn{3}{|c|}{ Physical features } & \multicolumn{3}{|c|}{ Parameters measured and used in this study } & \multirow{2}{*}{ 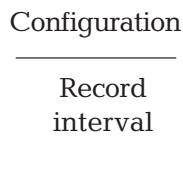 } \\
\hline Generic name & Type & Memory & $\begin{array}{l}\text { Dimensions } \\
(\mathrm{mm})\end{array}$ & $\begin{array}{l}\text { Weight } \\
\text { (g) }\end{array}$ & $\begin{array}{c}\text { Cross- } \\
\text { sectional } \\
\text { area }\left(\mathrm{cm}^{2}\right)\end{array}$ & $\begin{array}{l}\text { Pressure } \\
\text { (depth) }\end{array}$ & $\begin{array}{l}\text { Speed of } \\
\text { swim }\end{array}$ & $\begin{array}{l}\text { Sensor } \quad \text { Location } \\
\text { 'wet-dry' (lat.-long.) }\end{array}$ & \\
\hline $\begin{array}{l}\text { Time depth } \\
\text { recorder }\end{array}$ & $\begin{array}{r}\text { TDR } \\
\text { MK7 }\end{array}$ & $\mathrm{x}$ & $90 \times 20 \times 10$ & 30 & 2.2 & $\begin{array}{l}\text { Resolution } \\
\quad(1 \mathrm{~m})\end{array}$ & & $\mathrm{x}$ & $5 \mathrm{~s}$ \\
\hline $\begin{array}{l}\text { Time depth } \\
\text { recorder }\end{array}$ & $\begin{array}{l}\text { TDR } \\
\text { MK8 }\end{array}$ & $\mathrm{x}$ & $80 \times 50 \times 30$ & 100 & 8 & $\begin{array}{l}\text { Resolution } \\
\quad(1 \mathrm{~m})\end{array}$ & $\begin{array}{l}\text { Resolution } \\
\left(0.1 \mathrm{~m} \mathrm{~s}^{-1}\right)\end{array}$ & $\mathrm{x}$ & $5 \mathrm{~s}$ \\
\hline $\begin{array}{l}\text { Satellite } \\
\text { Argos system }\end{array}$ & $\begin{array}{r}\text { PTT } \\
100\end{array}$ & & $110 \times 42 \times 14$ & 120 & 5.7 & & & $\mathrm{x}$ & \\
\hline
\end{tabular}

(AW 2101, Ciba Speciality Chemicals). The seals were recaptured after 1 to 3 consecutive foraging trips (the trip duration ranged from $2.5 \mathrm{~h}$ to $6.5 \mathrm{~d}$ ). Devices were removed by cutting the fur underneath with a scalpel blade and subsequently deployed on different individuals. Individual devices were deployed alternately on the 2 species.

Activity budgets. The MK7 TDRs measured wet and dry periods and depth $( \pm 1 \mathrm{~m})$ every $5 \mathrm{~s}$ with a precalibrated pressure transducer. The MK8 TDRs also measured speed, with a pre-calibrated rotating turbine. The downloaded hexadecimal TDR files were converted into binary files using 'Hex Decoder' software (Wildlife Computers). Data were used to estimate the foraging-trip composition of the seals. We defined a foraging cycle (FC) as a trip to sea plus the subsequent period on land. In order to exclude short bathing periods undertaken by females during the suckling period on land, an individual was considered to undertake a foraging trip when at sea for $>1 \mathrm{~h}$.

The at-sea activity budget was calculated for each complete foraging trip recorded for each seal equipped with a MK8 TDR and defined as the amount of time dedicated to diving, travelling and resting. Diving activity was defined when depth was $>4 \mathrm{~m}$ (Lea et al. 2002). Travelling activity was defined when depth was $<4 \mathrm{~m}$ and speed was $>0$, while resting corresponded to the period in which fur seals were not diving and when speed equalled 0. All data manipulations and statistical analyses were conducted using R software (Ihaka \& Gentleman 1996).

The average swimming velocity, obtained from the MK8 data, was first compared between global foraging trips and next just on a section of a trip, where fur seals travelled regularly (Bonadonna et al. 2000). Therefore, a possible difference in the diving speed can be deduced.

Satellite transmitters and spatial distribution. PTT locations were calculated by reference to 3 satellites and assigned by the Argos system (Toulouse, France) to 6 classes on the basis of their estimated accuracy. The accuracy of locations provided by Argos is classified as follows: Class 3 is accurate to $150 \mathrm{~m}$; Class 2, to $350 \mathrm{~m}$; Class 1, to $1 \mathrm{~km}$; and Classes 0 , A and B have no accuracy assigned. Only 5 classes (A, 0, 1, 2, 3), allowing the location of animals with an error margin of $<4.5 \pm 5.9 \mathrm{~km}$ (Bonadonna et al. 2000), were included in these analyses. Data were plotted using Elsa99 software (release 1.0, Soft \& Technique Informatique). Locations were filtered such that those that suggested transit speeds $>3 \mathrm{~m} \mathrm{~s}^{-1}$ were excluded (Weimerskirch et al. 1995, Bost et al. 1997, Boyd et al. 1998, Bonadonna et al. 2000). The maximal distance from the colony reached by each seal was measured between the farthest point and the colony, and the total length of a foraging trip was obtained by summing all distances between 2 consecutive points of this trip. We also calculated a curvilinear index to determine the shape of each trip. Indeed, with this index, it was possible to determine whether the seal went to the foraging area directly or using a loop like some marine birds (Weimerskirch et al. 1993). The index was calculated by the following formula:

$$
S=(2 \times \text { maximal distance }) /(\text { total length of trip) }
$$

The closer this index is to 1 the more direct the trip is.

Females of the 2 species dive almost exclusively at night at Crozet (87 and $89 \%$ of dives occurred at night for Antarctic and Subantarctic fur seals, respectively (S. Luque unpubl. data). This result is coherent with diving behaviour of most fur seal species (Gentry \& Kooyman 1986, Goldworthy et al. 1997). As a result, only at-sea, night-time locations were used to evaluate the spatial distribution of foraging ground for both species. To determine the accurate limits of the night, we consulted a sun time table (suntab.exe software, www.cafe.rapidus.net/sbelange/logiciel.html). Moreover, to avoid problems of independence of the data, only 1 foraging trip for each animal was used in the analyses. 
In order to analyse the intensity of use of different areas within the activity range of seals, the pattern of locations (satellite fixes) must be transformed into an estimate of density. Therefore, a Kernel-based method, which transforms point distributions into density estimates (Powell 2000), was used. The treatment of data was conducted using the GIS software Arcview ${ }^{\circledR}$ (version 3.2, Esri Corporation) and 'Animal Movement' extension, v.2B (Hooge \& Eichenlaub 1997, Alaska Biological Science Center, www.absc.usgs.gov/glba/ gistools).

Environmental data. To investigate the relationships between the foraging areas and oceanographic features, bathymetric data (resolution of $5^{\prime}$ grid) were extracted from the Integrated Global Ocean Service System database (http://ingrid.ldeo.columbia.edu/ SOURCES/IGOSS/). In addition, sea surface temperature (SST) and chlorophyll a concentration data were provided by NOAA/NASA (http://daac.gsfc. nasa.gov/ oceancolor) at $4 \mathrm{~km}$ resolution and read by HDF view software (release 1.2, University of Illinois). These data were extracted from October 2001 to February 2002 and from October 2002 to February 2003. In addition to covering the dates of device deployment, this period covered the 2 mo prior to deployment, in order to observe the evolution of SST and chlorophyll $a$, as several studies have shown that time lags may result in a lag between the distribution of primary production and top predators (Runge 1988, Jaquet et al. 1995, Lehodey et al. 1998).

Statistical analysis. Some data were discarded due to TDR dysfunction or breakdown. A synthesis of the number of individuals equipped and the number used in the analysis is presented in Table 2. Parametric test application conditions were verified using a Kolmogorov-Smirnov test and a variance-equality test. If these conditions were not verified, data were transformed to use parametrics. However, when the transformation did not provide a normal distribution, we used non-parametric statistics. In the 'Results' section we have used some abbreviations for the species names: Ag = Arctocephalus gazella and At $=$ A. tropi- calis. Data are presented as means $( \pm \mathrm{SE})$, and values were considered significant at $\mathrm{p}<0.05$.

\section{RESULTS}

\section{Foraging cycles}

There was no effect of the individuals on all parameters tested $\left(\mathrm{n}_{\mathrm{Ag}}=26, \mathrm{n}_{\mathrm{At}}=34, \mathrm{p}>0.05\right.$ in each ANOVA). Therefore, we calculated means of all parameters for each individual. The type of logger affected trip duration $(F=8.011, \mathrm{p}<0.01$, GLM), with animals equipped with an MK8 TDR making longer trips than animals equipped with an MK7 TDR $(2.6 \pm 1.6 \mathrm{~d}$ against $1.7 \pm$ $1.38 \mathrm{~d}$, respectively). No significant differences were found between the 2 study years, for each species and each device type $\left(\mathrm{n}_{\mathrm{Ag}}=26, \mathrm{n}_{\mathrm{At}}=34, \mathrm{p}>0.05\right.$ in all $U$-tests). No effect of the month in which devices were deployed (stage of lactation) was found on any of the $\mathrm{FC}$ parameters investigated $\left(\mathrm{n}_{\mathrm{Ag}}=26, \mathrm{n}_{\mathrm{At}}=34, \mathrm{p}>0.05\right.$ in all Kruskal-Wallis tests). Therefore, all variables of the 2 study years were pooled for further the analyses.

No differences were observed in the length of foraging cycles between the 2 species equipped with MK7, but differences were found for animals equipped with MK8 (Table 3). Either equipped with MK7 or MK8, Antarctic fur seals had longer foraging trips than Subantarctic fur seals (Table 3). Consequently, Antarctic fur seals were found to spend proportionally more time at sea and less time ashore (Fig. 1), regardless of the type of TDR used (Table 3). No relationship was found between trip duration and time spent on land for the 2 species (Ag: $r_{s}=-0.02, p=0.90$ and At: $r_{s}=0.13, p=$ 0.44 , Spearman rank correlation test).

\section{At-sea activity budgets}

The activity budget could only be calculated for females of both species equipped with MK8 TDRs. We distinguished 3 different activities at sea: diving, travel-

Table 2. Summary of deployments and data analysis. Ag = Arctocephalus gazella, At $=$ A tropicalis. - : no data

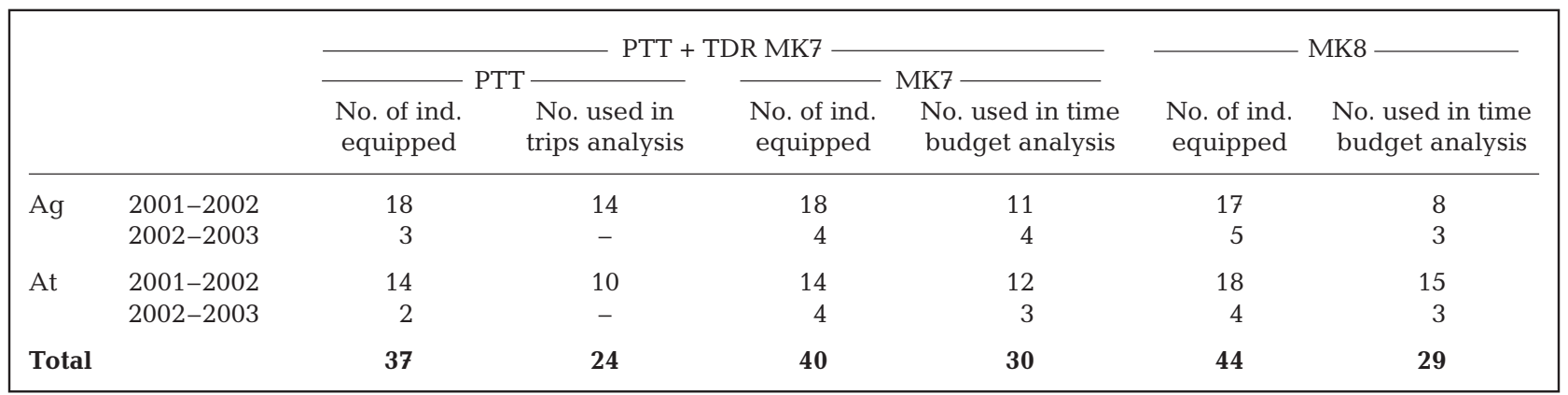


Table 3. Details of activity budget (the results are means $\pm \mathrm{SD}$, significant results are indicated in bold. -: no data

\begin{tabular}{|c|c|c|c|c|c|c|}
\hline & \multicolumn{3}{|c|}{ - MK7 } & \multicolumn{3}{|c|}{ - MK8 } \\
\hline & $\mathrm{Ag}, \mathrm{n}=15$ & At, $\mathrm{n}=15$ & Tests & $\mathrm{Ag}, \mathrm{n}=11$ & At, $n=18$ & Tests \\
\hline $\begin{array}{l}\text { Foraging } \\
\text { cycle (d) }\end{array}$ & $3.19 \pm 1.33$ & $2.70 \pm 1.67$ & $\begin{array}{l}U=144 \\
\mathrm{p}=0.191\end{array}$ & $4.52 \pm 1.39$ & $3.04 \pm 1.66$ & $\begin{array}{l}U=149 \\
\mathbf{p}=\mathbf{0 . 0 2 5}\end{array}$ \\
\hline $\begin{array}{l}\text { Trip } \\
\text { duration (d) }\end{array}$ & $2.09 \pm 0.98$ & $1.40 \pm 1.65$ & $\begin{array}{l}U=166 \\
\mathbf{p}=\mathbf{0 . 0 2 6}\end{array}$ & $3.61 \pm 1.41$ & $1.98 \pm 1.47$ & $\begin{array}{l}U=154 \\
\mathbf{p}=\mathbf{0 . 0 1 3}\end{array}$ \\
\hline $\begin{array}{l}\text { On land } \\
\text { duration (d) }\end{array}$ & $1.10 \pm 0.58$ & $1.30 \pm 0.74$ & $\begin{array}{l}U=92 \\
\mathrm{p}=0.395\end{array}$ & $0.90 \pm 0.74$ & $1.05 \pm 0.46$ & $\begin{array}{l}U=67 \\
\mathrm{p}=0.150\end{array}$ \\
\hline $\begin{array}{l}\text { Proportion of } \\
\text { time at sea (\%) }\end{array}$ & $64.2 \pm 9.9$ & $37.7 \pm 17.8$ & $\begin{array}{l}U=204 \\
\mathbf{p}<\mathbf{0 . 0 0 1}\end{array}$ & $76.1 \pm 16.0$ & $53.5 \pm 18.7$ & $\begin{array}{l}U=163 \\
\mathbf{p}=\mathbf{0 . 0 0 4}\end{array}$ \\
\hline $\begin{array}{l}\text { Proportion of } \\
\text { time in diving }(\%)\end{array}$ & $19.4 \pm 12.5$ & $18.0 \pm 8.6$ & - & $19.1 \pm 10.6$ & $18.6 \pm 8.5$ & KS test \\
\hline $\begin{array}{l}\text { Proportion of time } \\
\text { in swimming }(\%)\end{array}$ & - & - & - & $54.0 \pm 14.3$ & $54.7 \pm 8.5$ & $\begin{array}{l}D=0.268 \\
\mathrm{p}=0.695\end{array}$ \\
\hline $\begin{array}{l}\text { Proportion of time } \\
\text { in resting }(\%)\end{array}$ & - & - & - & $26.1 \pm 9.7$ & $20.7 \pm 14.2$ & \\
\hline
\end{tabular}

ling and resting. The proportions of time spent in diving, swimming and resting were identical for the 2 species $(D=0.268, \mathrm{p}=0.69$, Kolmogorov-Smirnov test). During a foraging trip, the 2 species devoted $18.8 \%$, on average, of the time to diving, $54.3 \%$, on average, to swimming and $23.4 \%$, on average, to resting (Table 3, Fig. 2). There were no relationships between the proportion of time spent swimming and trip duration for the 2 species (Ag: $r_{s}=-0.17, p=0.61, n=11$ and At: $r_{s}=-0.11, p=0.66, n=18$, Spearman rank correlation test), nor for the time spent diving for Antarctic fur seals $\left(\mathrm{r}_{\mathrm{s}}=0.2, \mathrm{p}=0.55, \mathrm{n}=11\right.$, Spearman rank correlation test), but this relationship tended towards significance for Subantarctic fur seals $\left(r_{s}=-0.44, p=0.07\right.$, $\mathrm{n}=18$, Spearman rank correlation test). In contrast, we observed a positive relationship between the propor-

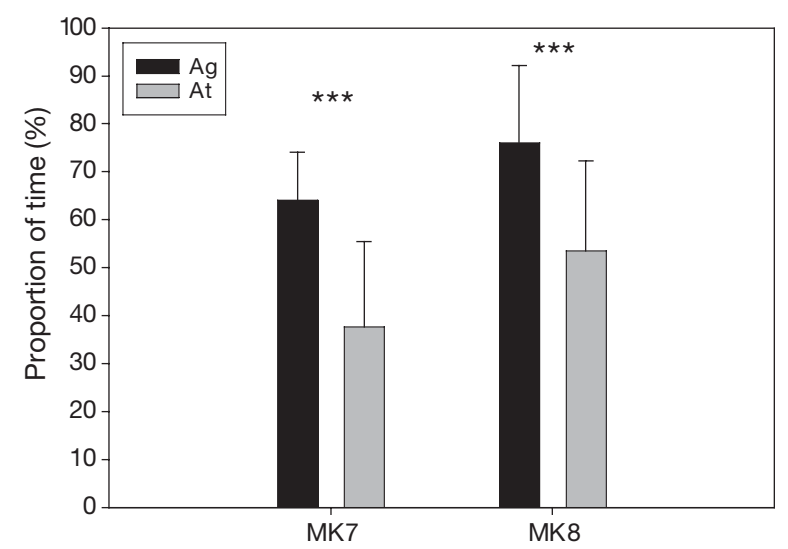

Fig. 1. Arctocephalus gazella (Ag), A. tropicalis (At). Proportion of time spent at sea during a foraging cycle (***: differences are significant at $99.9 \%$ ) tion of time spent resting at sea and the trip duration for Subantarctic fur seals $\left(r_{s}=0.58, p=0.01, n=18\right.$, Spearman rank correlation test), but not for Antarctic fur seals $\left(r_{s}=-0.14, p=0.67, n=11\right.$, Spearman rank correlation test). No differences were found in the proportion of time spent diving for females of both species equipped either an MK7 or an MK8 TDR (Table 3).

No difference was found in the overall swimming speed along a foraging trip between Antarctic fur seals $\left(0.61 \pm 0.15 \mathrm{~m} \mathrm{~s}^{-1}, \mathrm{n}=12\right)$ and Subantarctic fur seals $\left(0.54 \pm 0.17 \mathrm{~m} \mathrm{~s}^{-1}, \mathrm{n}=13 ; U=151, \mathrm{p}=0.18\right)$. Moreover, no differences were found in surface swimming speeds in transit to foraging grounds (Ag: $1.32 \pm 0.28 \mathrm{~m} \mathrm{~s}^{-1}, \mathrm{n}=$ 12; At: $\left.1.20 \pm 0.31 \mathrm{~m} \mathrm{~s}^{-1}, \mathrm{n}=13 ; U=98.5, \mathrm{p}=0.26\right)$. Consequently, it is very likely that no differences exist in the diving speeds.

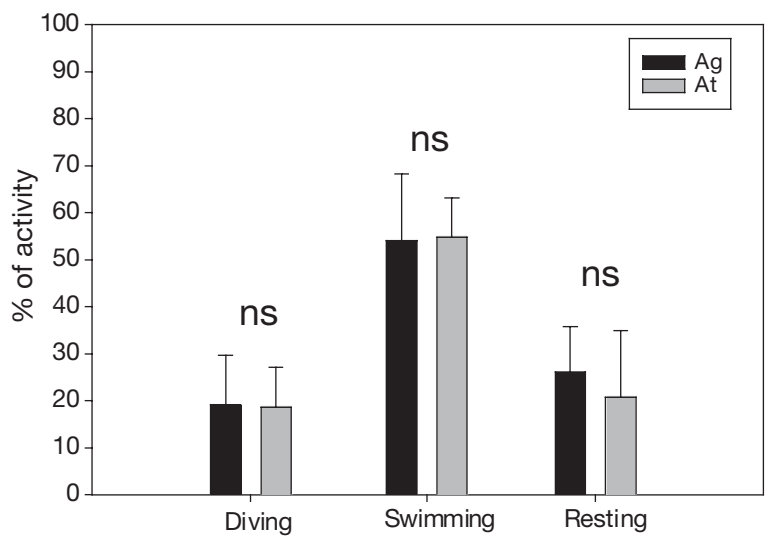

Fig. 2. Arctocephalus gazella (Ag), A. tropicalis (At). Proportion of time spent in the different activities at sea during a foraging trip (ns: differences are non-significant) 


\section{Foraging areas}

PTT tags recorded 39 foraging trips (31 in 2001/2002 and 8 in 2002/2003) for 29 individuals (14 Ag and $10 \mathrm{At}$ in 2001/2002 and $3 \mathrm{Ag}$ and 2 At in 2002/2003) during the study period. No difference was found in the number of locations (loc.) by unit of time between the 2 species (Ag: $16.64 \pm 8.22$ loc. $\mathrm{d}^{-1}, \mathrm{n}=17$; At: $14.12 \pm$ 6.99 loc. $\left.\mathrm{d}^{-1}, \mathrm{n}=12 ; t=1.135, \mathrm{p}=0.27\right)$. Trips recorded were divided thus: Ag: 9 trips in December and 8 in January, and At: 4 trips in December and 8 in January. No influence of the year or of the month during which devices were deployed was found on the number of locations by day ( $F=1.183, \mathrm{p}=0.35$, ANCOVA).

Two particularly long trips (>500 km), 1 for each species, were removed from Kernel analysis to increase accuracy of foraging areas in 2001/2002. Because of a very low sample size obtained during the second year of the study (2002/2003), trips recorded during this period (Ag: 3 trips and At: 2 trips) were removed from analyses. No overlap was observed between the foraging distributions of the 2 species. The Antarctic fur seals concentrated foraging activity preferentially in the west of Possession Island, while the Subantarctic fur seals occupied 2 main areas in the north-west and north of the island (Fig. 3). Both species foraged over the channel separating the Possession Island shelf from Hog Island.

No significant differences were found in the total trip lengths between the 2 species (Ag: $196 \pm 122 \mathrm{~km}$, $\mathrm{n}=14 ;$ At: $289 \pm 239 \mathrm{~km}, \mathrm{n}=10 ; U=145, \mathrm{p}=0.38$ ), but the Subantarctic fur seals went farther from the colony than the Antarctic fur seals (Ag: $50 \pm 27 \mathrm{~km}$, $\mathrm{n}=14$; At: $95 \pm 69 \mathrm{~km}, \mathrm{n}=10 ; U=100, \mathrm{p}<0.05)$. Moreover, we found a positive relationship between total length and trip duration for the Subantarctic fur seals $\left(\mathrm{r}_{\mathrm{s}}=0.905, \mathrm{p}<0.01\right)$, but no such relationship for the Antarctic fur seals $\left(r_{s}=0.314, p=0.56\right)$. Shape index indicates that the Antarctic fur seals used more trips with a loop structure compared to the Subantarctic fur seals, which used straighter trips (Ag: $0.56 \pm 0.17, \mathrm{n}=14 ;$ At: $0.72 \pm 0.18, \mathrm{n}=10 ; U=73$, $\mathrm{p}<0.01)$.

The Antarctic fur seals foraged mainly over 500 to $1500 \mathrm{~m}$ water depth, while Subantarctic fur seals tended to forage over $2000 \mathrm{~m}$ water depth (Fig. 3). Monthly averages of near-surface chlorophyll a concentrations from October 2001 to February 2002 are presented in Fig. 3. At the scale of the Crozet Archipelago, the distribution of chlorophyll a concentrations, prior to and during the 2001/2002 study period, showed that most of the surface primary production took place in the northern half of this archipelago, with highest concentrations taking place in December 2001 in the area where Subantarctic fur seals concentrated their foraging activity, while the Antarctic fur seals foraged along the southern edge of the area of the maximum chlorophyll a concentration.

\section{DISCUSSION}

In the present study we did not compare foraging trip duration between animals equipped and unequipped, but the effect of an additional burden on the behaviour of fur seals has already been taken into account in several earlier papers (Boyd et al. 1991, 1997, Walker \& Boveng 1995). However, we observed that the foraging trips of animals carrying MK8 TDRs were longer than the trips of PTT + MK7 TDRequipped seals, suggesting MK8 TDRs affect the foraging behaviour of the seals. Bonadonna et al. (2000) found similar results. It is interesting to note that both species were affected in a similar way by MK8 TDRs compared to MK7 TDRs. Indeed, compared to females equipped with MK7 TDRs, both Antarctic and Subantarctic female fur seals (Arctocephalus gazella, A. tropicalis) equipped with MK8 TDRs exhibited an increase in their foraging trip duration, while the subsequent shore visit was unchanged. Consequently and despite similar cross-sectional areas (about $8 \mathrm{~cm}^{2}$, see Table 1) of the 2 devices (MK8 and PTT + MK7), the proportion of time spent at sea for a foraging cycle in females of both species equipped with an MK8 TDR compared to females equipped with MK7 TDRs increased. Such consistent differences suggest that it is the hydraulic turbine of the MK8 TDRs that may be responsible for most of the drag effect during swimming compared to the other device. The biases introduced into the data are not a problem in a study that is based on the comparison between species subjected to the same treatment (MK8). Indeed, the biases are similar for the 2 species. Consequently, the conclusions would be correct in terms of the inter-specific comparison, while they should be considered more cautiously in terms of the absolute value of the foraging duration and possibly the relative percentage of activity.

\section{Activity budget}

Our results indicate that the duration of a foraging cycle and the proportion of time allocated during a foraging trip to different activities were identical among the 2 species. However, for a foraging cycle of a given duration, the at-sea part was longer for the Antarctic fur seals, resulting in a higher proportion of time spent at sea in the Antarctic fur seals compared to the Subantarctic fur seals. Indeed, over an average $3 \mathrm{~d}$ foraging cycle, the Antarctic female fur seals spent an aver- 

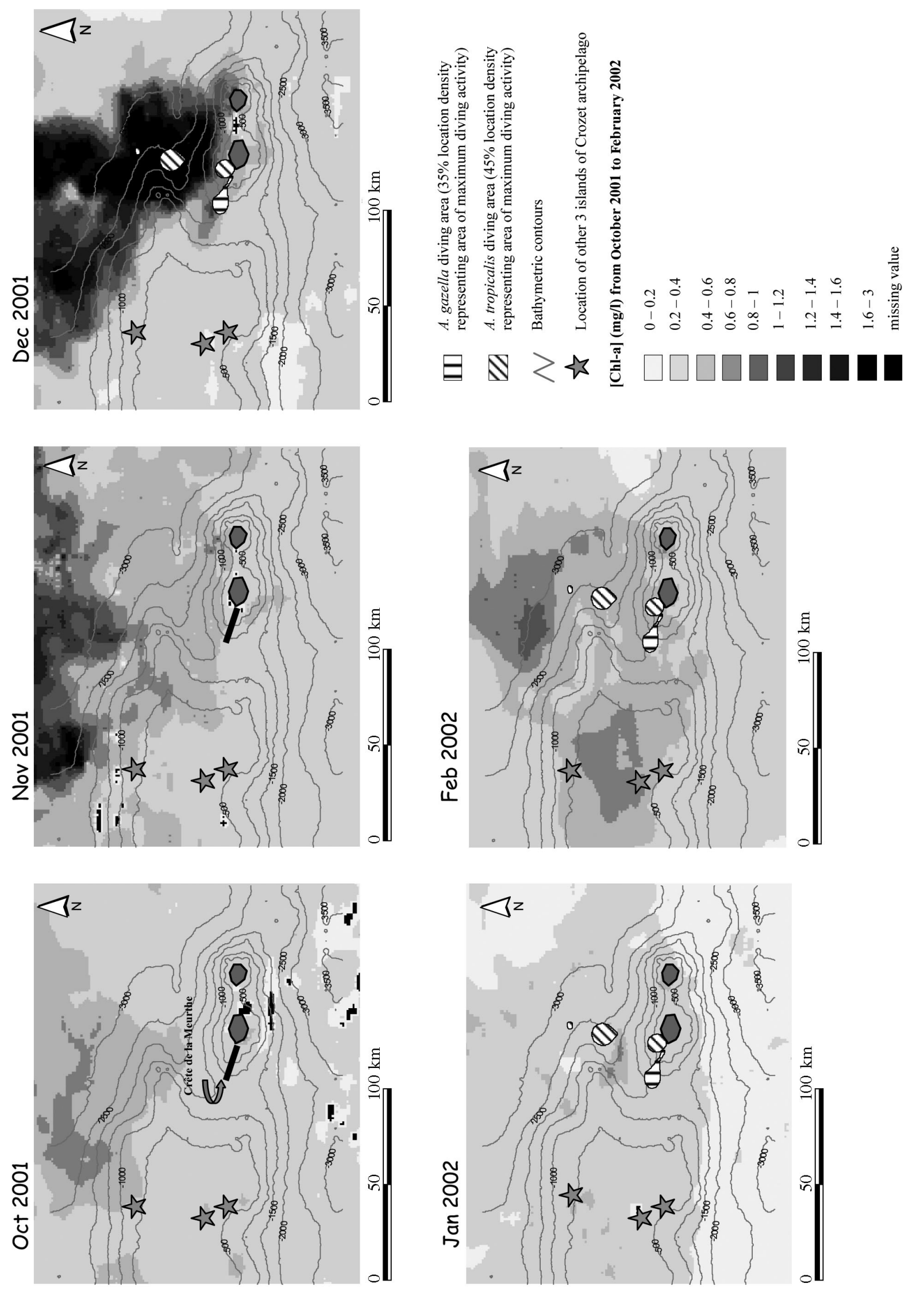

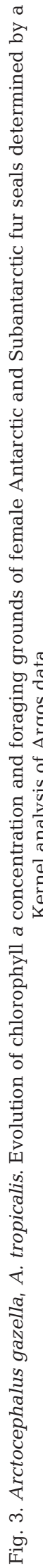


age of $24 \%$ more time at sea, but, more importantly, 1 night longer at sea than Subantarctic female fur seals. As both species fish almost exclusively at night at Crozet, we can assume that the absolute amount of resources acquired over a foraging trip is higher in the Antarctic fur seals compared to the Subantarctic fur seals, resulting from a higher energy acquisition rate over a foraging cycle for the Antarctic fur seals than for the Subantarctic fur seals. No precise values of energetic metabolism are available for this study, but Costa et al. (1989), using the double-marked water method, measured a metabolism at sea of $9.52 \mathrm{~W} \mathrm{~kg}^{-1}$ for lactating females. They also found that the at-sea metabolism of the Antarctic fur seal females was only 1.9 times higher than the metabolism measured on land while fasting and lactating (Costa et al. 1989). Similar results were found for the Alaska fur seals Callorhinus ursinus (Costa \& Gentry 1986). To our knowledge, no measurements of resting or active metabolism are available for Subantarctic fur seals. However, according to the allometric relation between the rate of base metabolism and body mass, established for pinnipeds by Lavigne et al. (1986), we can suppose that metabolism is equivalent for our 2 study models, which are taxonomically and morphologically very similar. Indeed, it is unlikely, even if there is a need to confirm this by measuring the actual metabolic rate of these 2 species at Crozet, that these species, with an identical at-sea behaviour ( $\mathrm{S}$. Luque unpubl. data), have very different metabolic rates. Thus, considering both identical metabolic rates at sea and on land between the 2 species, we can estimate at Crozet, due to the difference in the proportion of time spent at sea, that the Antarctic fur seals spent about $13 \%$ more energy than Subantarctic fur seals over a foraging cycle.

Arnould \& Boyd (1996) found a negative relationship between the proportion of time spent diving and the at-sea metabolic rate for Antarctic fur seals at Bird Island, South Georgia. According to Butler et al. (1995), the metabolism during diving is only $20 \%$ higher than the metabolism during swimming for the Antarctic fur seal. The interpretation of Arnould \& Boyd (1996) was based on the hypothesis that an animal with a higher rate of diving should spend more time resting at the surface to recover and should have a lower at-sea metabolic rate than an animal with a lower rate of diving, but spending more time swimming. However, opposite from this assumption, we found no relationship between the proportion of time spent diving and proportion of time spent resting. This result could be explained by the smaller range of trip durations sampled at Crozet Islands ( $2 \mathrm{~d}$ for both species) compared to Bird Island (4 d on average). We can therefore hypothesise that during foraging trips taking place close to the colony, as in our study, fur seals tend to come back on land to rest and suckle their pup, rather than resting at sea. The relationship between foraging trip duration and the proportion of time females spent resting and the relationship between foraging trip duration and the maximum distance from the colony support this assumption.

\section{Foraging trip distribution in relation to oceanographic parameters}

Maximum location densities were identified using the main foraging areas of the 2 species. The technique used may be biased, as the at-sea, night-time locations do not necessarily correspond to a foraging location. However, as the foraging activity is maximal at night, we can consider that these locations reveal the foraging areas of both species.

As ocean currents encounter topographic features such as seamounts, oceanic islands, or ridges, cold and deep nutrient-rich waters can be brought into the generally nutrient-poor surface water, enhancing primary production. Topographic features can also induce local aggregation of marine organisms (Lavoie et al. 2000). Advection processes would induce the aggregation process at medium to large scale, over several months, while at a smaller scale appears to result mainly from accumulation processes and behavioural and/or physiological adaptation (Mackas et al. 1985). Local aggregations are generally related to small-scale processes that are often related to a topographic change, which may indirectly act on the marine organisms.

The Subantarctic fur seals tended to forage both in an area located over the deeper water of the channel between Possession Island and Hog Island and in an area close to shore, while the Antarctic female fur seals limited their foraging to a much smaller area located on the northern edge of the 'Crête de la Meurthe', a sub-marine ridge close to Possession Island. A complementary study on the diet of the 2 species at Crozet (Y. Cherel unpubl. data) showed that the Antarctic and Subantarctic fur seals fed on the same myctophid prey organisms (principally Gymnoscopelus sp. and Electrona sp.).

The distribution of surface chlorophyll a over the study period indicates that the highest concentration takes place in December over that channel, and the fact that both species concentrate their foraging activity over or very close to that area from December to early March suggests that the myctophids are probably aggregated over that area in relation to some still unknown physical processes.

The absence of major differences, both in diving behaviour (S. Luque unpubl. data) and diet (Y. Cherel 
unpubl. data), suggests that both species are exploiting similar prey in a similar way, but in different locations. At this stage we cannot tell if this behaviour results from active competition exclusion processes and/or the selection of different qualities of foraging habitat by the 2 species. We can hypothesise that the Antarctic fur seals, which have higher needs per unit of time, could restrict their foraging behaviour to higher density prey patches, located on the northern edge of the 'Crête de la Meurthe', compared to Subantarctic fur seals, which use a less efficient foraging mode because of greater transit time (temporally shorter and spatially longer trips). Only a myctophid sampling survey like the one conducted at Kerguelen Island (Duhamel 1987, Guinet et al. 2001) will clarify these patterns.

\section{CONCLUSIONS}

Interestingly, when these 2 species are confronted with the same environmental conditions, they tend to show similar foraging behaviour, while the same species in different environments exhibit very different foraging behaviours. These observations strongly support the assertion that the foraging behaviour of fur seal species is mainly mediated by local environmental conditions.

This study also found, like another one at Macquarie Island (Robinson et al. 2002), that these sympatric fur seals exploited the marine environment in similar ways. However, the higher proportion of time spent at sea by female Antarctic fur seals compared to Subantarctic fur seals suggests that lactating female Antarctic fur seals expend more energy to acquire more energy per unit of time to match the higher energetic requirement of their pups compared to Subantarctic fur seals. This higher energy expenditure assumed in lactating female Antarctic fur seals is consistent with a shorter lactation period that still allows pups to grow to a weaning mass similar to that of Subantarctic fur seal pups over a longer lactation period.

Acknowledgements. This work was supported by Institut Paul Emile Victor (IPEV) and by the Territoire des Terres Australes et Antarctiques Françaises (TAAF). The authors would like to thank the members of the 38th, 39th and 40th research mission at Crozet Island for their assistance in the field. We wish particularly to thank T. Cook, J. Kingston, M. Chambellant, N. Servera, F. Pawlowski, M. Le Corre and Y. Cherel for the analysis of scats and D. Pinaud for helpful advice with GIS. We also thank all the members of the Centre d'Etudes Biologiques de Chizé for their assistance with small daily problems. Many thanks to the anonymous reviewers for suggestions to improve this manuscript.

\section{LITERATURE CITED}

Arnould JPY, Boyd IL (1996) The relationship between foraging behaviour and energy expenditure in Antarctic fur seals. J Zool Lond 239:769-782

Arnould JPY, Luque SP, Guinet C, Costa DP, Kingston J, Schaffer SA (2003) The comparative energetics and growth strategies of sympatric Antarctic and Subantarctic fur seal pups at Iles Crozet. J Exp Biol 206:4497-4506

Beauplet G, Dubroca L, Guinet C, Cherel Y, Dabin W, Gagne C, Hindell M (2004) Foraging ecology of Subantarctic fur seals (Arctocephalus tropicalis) breeding on Amsterdam Island: seasonal changes in relation to maternal characteristics and pup growth. Mar Ecol Prog Ser 273:211-225

Bonadonna F, Lea MA, Guinet C (2000) Foraging routes of Antarctic fur seal (Arctocephalus gazella) investigated by the concurrent use of satellite tracking and time-depth recorders. Polar Biol 23:149-159

Bonner WN (1984) Lactation strategies in pinnipeds: problems for a marine mammalian group. Symp Zool Soc Lond 51:253-257

Bost CA, Georges JY, Guinet C, Cherel Y and 6 others (1997) Foraging habitat and food intake of satellite-tracked king penguins during the austral summer at Crozet Archipelago. Mar Ecol Prog Ser 150:21-33

Boyd IL (1999) Foraging and provisioning in Antarctic fur seals: interannual variability in time-energy budgets. Behav Ecol 10:198-208

Boyd IL, Lunn NJ, Barton T (1991) Time budgets and foraging characteristics of lactating antarctic fur seals. J Anim Ecol 60:577-592

Boyd IL, MacCafferty DJ, Walker TR (1997) Variation in foraging effort by lactating Antarctic fur seal: response to simulated increased foraging costs. Behav Ecol Sociobiol 40:135-144

Boyd IL, MacCafferty DJ, Reis K, Taylor R, Walker TR (1998) Dispersal of male and female Antarctic fur seals (Arctocephalus gazella). Can J Fish Aquat Sci 55:845-852

Butler PJ, Bevan RM, Woakes AJ, Croxall JP, Boyd IL (1995) The use of data loggers to determine the energetics and physiology of aquatic birds and mammals. Braz J Med Biol Res 28:1307-1317

Charnov EL (1976) Optimal foraging, the marginal value theorem. Theo Popul Biol 9:129-136

Costa DP, Gales NJ (2003) Energetics of a benthic diver: seasonal foraging ecology of the Australian sea lion, Neophoca cinerea. Ecol Monogr 73:27-43

Costa DP, Gentry RL (1986) Free-ranging energetics of northern fur-seals. In: Gentry RL, Kooyman GL (eds) Fur seals: maternal strategies on land and at sea. Princeton University Press, Princeton, NJ, p 19-101

Costa DP, Croxall JP, Duck CD (1989) Foraging energetics of Antarctic fur seals in relation to changes in prey availability. Ecology 70:596-606

Duhamel G (1987) Distribution and abundance of fish on the Kerguelen islands shelf. In: Kullander SO, Fernholm B (eds) Proc V Congr Eur Ichthyol Stockholm, 1985, Swedish Museum of Natural History, Stockholm, p 397-403

Gentry RL, Kooyman GL (1986) Fur seals: maternal strategies on land and at sea. Princeton University Press, Princeton, NJ

Georges JY, Bonadonna F, Guinet C (2000) Foraging habitat and diving activity of lactating subantarctic fur seals in relation to sea surface temperatures at Amsterdam Island. Mar Ecol Prog Ser 196:291-304

Goldworthy SD, Hindell MA, Crowley HM (1997) Diet and diving behaviour of sympatric fur seals, Arctocephalus 
gazella and A. tropicalis, at Macquarie Island. In: Hindell MA, Kemper C (eds) Marine mammal research in the southern hemisphere: status, ecology and medicine. Surrey Beatty \& Sons, Chipping Norton, p 151-163

Guinet C, Jouventin P, Georges JY (1994) Long term population changes of fur seals Arctocephalus gazella and A. tropicalis on Subantarctic (Crozet) and subtropical (St Paul and Amsterdam) islands and their possible relationship to El Niño Southern Oscillation. Antarct Sci 6: $473-478$

Guinet C, Koudil M, Bost CA, Durbec JP, Georges JY, Mouchot MC, Jouventin P (1997) Foraging behavior of satellite-tracked king penguins in relation to sea-surface temperatures obtained by satellite telemetry at Crozet Archipelago, a study during 3 austral summers. Mar Ecol Prog Ser 150:11-20

Guinet C, Dubroca L, Lea MA, Goldsworthy S, Cherel Y, Duhamel G, Bonadonna F, Donnay JP (2001) Spatial distribution of foraging in female Antarctic fur seals Arctocephalus gazella in relation to oceanographic variables: a scale-dependent approach using geographic information systems. Mar Ecol Prog Ser 219:251-264

Hooge PN, Eichenlaub B (1997) Animal movement extension to Arcview. Alaska Biological Science Center, US Geological Survey, Anchorage, AK

Houston AI (1995) Energetic constraints and foraging efficiency. Behav Ecol 6(4):393-396

Hutchinson GE (1957) Concluding remarks. Cold Spring Harbor Symp Quantitative Biol 22:415-527

Ihaka R, Gentleman R (1996) R: a language for data analysis and graphics. J Comput Graph Stat 5:299-314

Jaquet N, Whitehead H, Lewis M (1995) Relationship between sperm whale distribution and primary productivity over large spatial scale in the Pacific Ocean. Eur Res Cetac 9:188-192

Kerley GIH (1985) Pup growth in the fur seals Arctocephalus tropicalis and A. gazella on Marion Island. J Zool Lond 205:315-324

Lavigne DM, Innes S, Worthy GAJ, Kovacs KM, Schmitz OJ, Hickie JP (1986) Metabolic rates of seals and whales. Can J Zool 64:279-284

Lavoie D, Simard Y, Saucier FJ (2000) Aggregation and dispersion of krill at channel heads and shelf edges: the dynamics in the Sagvenay-St Lawrence Marine Park. Can J Fish Aquat Sci 57:1853-1869

Lea MA, Hindell MA, Guinet C, Goldsworthy S (2002) Variability in the diving activity of Antarctic fur seals, Arctocephalus gazella, at Iles Kerguelen. Polar Biol 25:269-279

Lehodey $\mathrm{P}$, André JM, Bertignac M, Hampton J, Stoens A, Menkes C, Mémery L, Grima N (1998) Predicting skipjack tuna forage distributions in the equatorial Pacific using a coupled dynamical biogeochemical model. Fish Oceanogr $7(3 / 4): 317-325$

Editorial responsibility: Otto Kinne (Editor-in-Chief), Oldendorf/Luhe, Germany
Loeb V, Siegel V, Holm-Hansen O, Hewitt R, Fraser W, Trivelpiece W, Trivelpiece S (1997) Effects of sea-ice extent and krill or salp dominance on the Antarctic food web. Nature 387:897-900

MacArthur RH, Pianka ER (1966) On optimal use of a patchy environment. Am Nat 100:603-609

MacCafferty DJ, Boyd IL, Walker TR, Taylor RI (1998) Foraging responses of Antarctic fur seals to changes in the marine environment. Mar Ecol Prog Ser 166:285-299

Mackas DL, Denman K, Abolt MR (1985) Phytoplankton patchiness: biology in the physical vernacular. Bull Mar Sci 37:652-674

Orians GH, Pearson NE (1979) On the theory of central place foraging. In: Horn DJ, Stairs GR, Mitchell RD (eds) Analysis of ecological systems. Ohio State University Press, Columbus, OH, p 155-177

Pakhomov EA, McQuaid CD (1996) Distribution of surface zooplankton and seabirds across the Southern Ocean. Polar Biol 16:271-286

Powell RP (2000) Animal home ranges and territories and home range estimators. In: Boitani L, Fuller TK (eds) Research techniques in animal ecology: controversies and consequences. Columbia University Press, New York, p 65-110

Robinson SA, Goldworthy SG, Van den Hoff J, Hindell MA (2002) The foraging ecology of two sympatric fur seal species, Arctocephalus gazella and A. tropicalis, at Macquarie Island during the austral summer. Mar Freshw Res 53:1071-1082

Runge JA (1988) Should we expect a relationship between primary production and fisheries? The role of copepod dynamics as a filter of trophic variability. Hydrobiologia 167/168:61-71

Walker BG, Boveng P (1995) Effects of time-depth recorders on maternal foraging and attendance behavior of Antarctic fur seals Arctocephalus gazella. Can J Zool 73: 1538-1544

Weimerskirch H (1998) Foraging strategies of Indian Ocean albatrosses and their relationship with fisheries. In: Robertson G, Gales R (eds) Albatross: biology and conservation. Surrey Beatty \& Sons, Chipping Norton, p 168-179

Weimerskirch $\mathrm{H}$, Salamolard M, Sarrazin F, Jouventin P (1993) Foraging strategy of wandering albatrosses through the breeding season: a study using satellite telemetry. Auk 110:325-342

Weimerskirch H, Wison RP, Guinet C, Koudil M (1995) The use of seabirds to monitor sea-surface temperatures and to validate satellite remote-sensing measurements in the Southern Ocean. Mar Ecol Prog Ser 126:299-303

Ydenberg RC, Welham CVJ, Schmid-Hempel R, SchmidHempel P, Beauchamp G (1994) Time and energy constraints and the relationships between currencies in foraging theory. Behav Ecol 5(1):1045-2249

Submitted: June 8, 2004; Accepted: December 16, 2004 Proofs received from author(s): May 2, 2005 